\title{
HISTOPATHOLOGICAL STUDY OF PLACENTA IN ANAEMIA OF PREGNANCY IN RURAL PUDUCHERRY
}

\author{
Rajesh Kumar $M^{1}$, Rathna $S^{2}$, Sowmya $S^{3}$, Gandhi $N^{4}$, Venkatraman $J^{5}$ \\ ${ }_{1}^{1}$ Postgraduate Student, Department of Pathology, Sri Manakula Vinayagar Medical College and Hospital, Puducherry. \\ ${ }^{2}$ Associate Professor, Department of Pathology, Sri Manakula Vinayagar Medical College and Hospital, Puducherry. \\ 3 Professor and HOD, Department of Pathology, Sri Manakula Vinayagar Medical College and Hospital, Puducherry. \\ 4 Professor, Department of Pathology, Sri Manakula Vinayagar Medical College and Hospital, Puducherry. \\ ${ }_{5}^{5}$ Assistant Professor, Department of Pathology, Mahatma Gandhi Medical College and Research Institute, Puducherry.
}

\section{ABSTRACT}

\section{BACKGROUND}

Placenta is a mirror which reflects the intrauterine status of the foetus. It is a vital organ for maintaining and promoting normal foetal development. It undergoes different changes in weight, volume, structure, shape and function continuously throughout the gestation to support the prenatal life. Anaemia during pregnancy is one of the common and serious haematological disorder which causes changes in the structure of placenta, profound changes on the maternal circulatory system and it has serious effects both on mother and foetus. The examination of placenta in-utero as well as postpartum provides insight into prenatal health of baby and mother.

The study was undertaken to identify the histomorphological findings of all placentas and to correlate normal and abnormal placental findings in relation to anaemia of pregnancy.

\section{MATERIALS AND METHODS}

Fifty placental specimens from mothers who had anaemia of pregnancy and fifty placental specimens from mothers who had normal antenatal period were taken up for the study. The specimens were received in the Department of Pathology, Sri Manakula Vinayagar Medical College and Hospital for a period of 2 years and were studied. The clinical data related to mother and foetus were recorded. The macroscopic appearance of the placenta was documented. Representative bits were given for routine processing and stained with Haematoxylin and Eosin stain for detailed microscopic study.

\section{RESULTS}

Placental weight, umbilical cord length and birth weight were reduced in placenta of anaemia group in comparison with control group. Increased incidence of increase in number of cotyledons, calcification and infarction was noted in placenta of anaemia group as compared to control group. The microscopic parameters like syncytial knots, calcification, infarction, fibrinoid necrosis and fibrotic villi were increased with decreased villous vascularity in anaemia group in comparison with control group. In all these variables, $p$ value was found to be statistically significant.

\section{CONCLUSION}

Anaemia in pregnancy alters the placental morphology. Early recognition of anaemia and proper management may therefore be crucial for normal placental function. Thus, we conclude that histopathological examination of placenta is indispensable and has to be carried out as a routine protocol.

\section{KEYWORDS}

Placenta, Anaemia, Macroscopy, Microscopy.

HOW TO CITE THIS ARTICLE: Kumar RM, Rathna S, Sowmya S, et al. Histopathological study of placenta in anaemia of pregnancy in rural Puducherry. J. Evolution Med. Dent. Sci. 2016;5(96):7071-7075, DOI: 10.14260/jemds/2016/1600

\section{BACKGROUND}

Placenta is a mirror which reflects the intrauterine status of the foetus. It is a vital organ for maintaining and promoting normal foetal development. It connects the developing foetus to the uterine wall thereby allowing nutrient uptake, waste elimination and gas exchange via mother's blood supply. ${ }^{1}$ It is an important organ for the continuation of pregnancy and

Financial or Other, Competing Interest: None.

Submission 11-11-2016, Peer Review 23-11-2016,

Acceptance 26-11-2016, Published 01-12-2016.

Corresponding Author:

Dr. Venkatraman J,

Assistant Professor,

Department of Pathology,

Mahatma Gandhi Medical College and

Research Institute, Puducherry.

E-mail: drvenkatraman1983@gmail.com

DOI: $10.14260 /$ jemds $/ 2016 / 1600$ foetal nutrition and has evoked great interest among pathologist and obstetrician to understand the unique biological status of this complex organ. ${ }^{2}$ The examination of placenta in-utero as well as postpartum provides much insight into prenatal health of baby and mother. ${ }^{3}$

Anaemia during pregnancy is one of the common and serious haematological disorders, which is associated with late abortions, prematurity, low birth weight and stillbirths. 4 Severity of anaemia among pregnant women is assessed based on haemoglobin percentage suggested by WHO. A level of haemoglobin below $11 \mathrm{~g} / \mathrm{dL}$ during pregnancy is considered anaemia. ${ }^{5}$ The commonest aetiological cause for anaemia during pregnancy is iron deficiency which is mainly due to nutritional deficiency or increased demand in pregnancy. Anaemia leads to hypoxia and causes changes in structure of placenta, profound changes on the maternal circulatory system and has serious effects both on mother and foetus. ${ }^{5}$ Since placenta can show various macroscopic and microscopic 
changes in maternal and foetal disease process, the current study was conducted in relation to the aetiology.

\section{MATERIALS AND METHODS}

It is a descriptive study on placental specimens which were received in the Pathology Department of Sri Manakula Vinayagar Medical College and Hospital from October 2014May 2016. Fifty placental specimens from mothers who had anaemia of pregnancy and fifty placental specimens from mothers who had normal antenatal period were included for the study after obtaining Ethical Committee Clearance.

\section{The following were included in Control Group}

- $\quad$ Singleton uncomplicated term pregnancy.

- $\quad$ Baby weight $>2.5 \mathrm{Kg}$.

- Gestational period $>37-41$ weeks.

- Blood pressure $<140 / 90 \mathrm{~mm}$ of $\mathrm{Hg}$ throughout pregnancy.

- Age matched non-anaemic mothers whose haemoglobin value was $11 \mathrm{~g} / \mathrm{dL}$ and above.

\section{The following were included in Anaemia Group}

- Singleton pregnancy.

- Gestational period $>37-41$ weeks.

- Blood pressure $<140 / 90 \mathrm{~mm}$ of $\mathrm{Hg}$ throughout pregnancy.

- Anaemic patients whose haemoglobin value below $11 \mathrm{~g} / \mathrm{dL}$ were included in the study.

Conditions such as associated obstetric complications of pregnancy, associated medical disorders of pregnancy and multiple pregnancies (e.g. twins, etc.) were excluded from the study.

The clinical data related to mother, foetus and the mode of delivery was recorded. The placentas from both control and anaemia groups were collected immediately following expulsion, and washed in the running tap water to remove the blood clots. The shape (round or oval) of the placenta was assessed by stretching it flat on the cutting board. The weight of the placenta was measured on a standard weighing scale. Placental diameter was measured using a thread and the thickness was measured at the centre of placenta after giving serial cuts. The foetal surface was examined for colour, transparency, subchorionic thrombus, insertion of umbilical cord and attachment of foetal membranes. The extra placental membranes were inspected for completeness, adherent blood clot, colour and transparency. The umbilical cord length was measured and it was examined for the number of vessels, true knots, false knots and insertion (central, eccentric or velamentous). The membranes were trimmed and a strip was taken as "Swiss roll". The cord was cut at about $4 \mathrm{~cm}$ from its insertion. The cut end of the cord was examined for the number of blood vessels. Portions of the cord from the proximal and distal regions were taken for paraffin embedding. The maternal surface of the placenta was inspected for completeness, adherent blood clots, number of cotyledons, calcification and infarction. The whole placenta was left for fixation in $10 \%$ formal saline for 24-48 hours. After fixation, the placenta was cut into vertical strips (bread loaf manner) of $0.5 \mathrm{~cm}$ thickness each and the macroscopic lesions were examined. The villous parenchyma was examined for calcification, infarction and intervillous thrombosis. The tissue bits for microscopic examination were taken from cut end of umbilical cord, at placental junction, strip of membrane roll, margins of placenta, central area of placenta, any fibrotic area, any calcified area and any infarcted area. The tissue bits were then processed through series of dehydration steps and embedded in wax blocks. Tissue sections of $5 \mu \mathrm{m}$ thicknesses were cut from paraffin embedded blocks and stained by conventional Haematoxylin and Eosin (H \& E) stain.

Different histological features were quantified. One hundred terminal villi were counted in the maternal subdivision of each of the sections. Thus, in each placenta four hundred villi were counted and the incidences of various histological features were determined. The mean numbers of villi showing syncytial knots, vasculosyncytial membrane, fibrinoid necrosis, infarction, calcification and villous stromal fibrosis were determined.

\section{Evaluation of Macroscopic Lesions Infarction}

Infarction was noted and confirmed on microscopic examination. Placentas were classified according to the presence or absence of infarction and expressed as percentage.

\section{Calcification}

Calcification was noted and confirmed on microscopic examination. Placentas were classified according to the presence or absence of calcification.

\section{Evaluation of Histological Features Villous Vascularity}

The number of villi showing normal vascularity, increased vascularity or decreased vascularity was recorded and the results were expressed as a percentage of the total villi.

\section{Syncytial Knots}

The number of villi with syncytial knots was recorded and the results were expressed as a percentage. A true syncytial knot was only accepted as such if it was visible on low power magnification and the counts were carried out using high power magnification.

\section{Fibrinoid Necrosis}

The number of villi showing fibrinoid necrosis was noted and the total of such villi was then expressed in percentage.

\section{Fibrosis of Villi}

The number of fibrotic villi was expressed as a percentage. An individual villus was classed as "normal" or "fibrotic".

The different histological findings were observed against the background of normal standards of histology of placenta as described by Stacey et $\mathrm{al}^{6}$ and Fox H. ${ }^{7}$

\section{Statistical Analysis}

All the gross and histological features were compared between the placenta of anaemia group and control group. The data was arranged in excel workbook under suitable headings. The mean, standard deviation and standard error was calculated for different parameters. They were statistically analysed using Chi square test for qualitative variables and Student ' $\mathrm{t}$ ' test for quantitative variables. This was done using EPI info version 3.5.3. In all the tests, 'p' value less than 0.05 was taken to be statistically significant. 


\section{RESULTS}

During the study period, fifty placental specimens from mothers who had anaemia of pregnancy were studied. The macroscopic and microscopic features of these specimens were compared with fifty placental specimens from the control group. Of the 50 anaemia cases, 21 (42\%) were primigravida and 29 (58\%) were multigravida suggesting that anaemia is more common in multigravida. Mean birth weight between anaemia group $(2375.0 \pm 329.08)$ was less when compared to control group $(2932.0 \pm 209.17)$. Mean placental weight in anaemia group $(438.0 \pm 40.56)$ was less when compared to control group $(476.8 \pm 33.16)$.

The correlation between birth weight and placental weight was calculated using Pearson correlation coefficient. Among anaemic mothers, the correlation coefficient was 0.62 , positive which indicates as placental weight increases birth weight also increases. Among control group, the correlation coefficient was 0.55 , positive and statistically significant which indicates as placental weight increases birth weight also increases. Placental coefficient is defined as the ratio of placental weight to foetal weight. Normally it is 0.10 to 0.18 . Mean placental coefficient between anaemia groups $(0.18 \pm 0.02)$ was more when compared to control group $(0.17 \pm 0.01)$ (Table 1$)$.

The mean length of the umbilical cord in anaemia group was $49.72 \pm 5.29 \mathrm{~cm}$ and that in control group was $54.46 \pm 3.12$ $\mathrm{cm}$. Hence, in the current study, umbilical cord length was significantly less in anaemia group. Calcification was seen in $12(24 \%)$ placentas of anaemia group and $4(8 \%)$ placentas of control group. Infarction was seen in $28(56 \%)$ placentas of anaemia group and 9 (18\%) of control group (Table 2).

The mean number of cotyledons seen in placenta of the anaemia group was $18.9 \pm 3.02$ and that in control group was $17.46 \pm 1.58$. Syncytial knots were present on more than $30 \%$ of the villi in $32(64 \%)$ placentas of the anaemia group and 7 (14\%) placentas of the control group. Hence, increased proportion of placenta in anaemia group showed syncytial knots on more number of villi when compared to control group (Table 3).

$40 \%$ of villous vascularity in anaemic patients was normal compared to $70 \%$ in control group. $10 \%$ of villous vascularity in anaemic patients was increased compared to $18 \%$ in control group. $50 \%$ of villous vascularity in anaemic patients was decreased compared to $12 \%$ in control group (Table 4).

Fibrinoid necrosis was seen in more than $3 \%$ of the villi in $29(58 \%)$ placentas of the anaemia group and $4(8 \%)$ placentas of the control group (Table 5). Fibrosis of villi was seen in more than $3 \%$ of the villi in $29(58 \%)$ placentas of the anaemia group and $4(8 \%)$ placentas of the control group (Table 6).

\begin{tabular}{|c|c|c|c|}
\hline Parameters & $\begin{array}{c}\text { Anaemia } \\
(\mathbf{n}=50)\end{array}$ & $\begin{array}{c}\text { Control } \\
(\mathbf{n = 5 0 )}\end{array}$ & $\begin{array}{c}\mathbf{p} \\
\text { value }\end{array}$ \\
\hline $\begin{array}{c}\text { Birth Weight } \\
\text { (g) }\end{array}$ & $2375.0 \pm 329.08$ & $2932.0 \pm 209.17$ & $<0.001^{*}$ \\
\hline $\begin{array}{c}\text { Placental } \\
\text { Weight (g) }\end{array}$ & $438.0 \pm 40.56$ & $476.8 \pm 33.16$ & $<0.001^{*}$ \\
\hline $\begin{array}{c}\text { Placental } \\
\text { Coefficient }\end{array}$ & $0.18 \pm 0.02$ & $0.17 \pm 0.01$ & $<0.001^{*}$ \\
\hline \multicolumn{3}{|c|}{ Table 1. Association of Mean Birth Weight, } \\
Placental Weight and Placental Coefficient \\
in Anaemia Group and Control Group
\end{tabular}

\begin{tabular}{|c|c|c|c|c|c|c|c|}
\hline \multirow[t]{2}{*}{$\begin{array}{l}\text { Sl. } \\
\text { No. }\end{array}$} & \multirow[t]{2}{*}{$\begin{array}{l}\text { Macro- } \\
\text { scopic } \\
\text { Lesions }\end{array}$} & \multicolumn{2}{|c|}{$\begin{array}{c}\text { Anaemia } \\
\text { Group } \\
(n=50)\end{array}$} & \multicolumn{2}{|c|}{$\begin{array}{c}\text { Control } \\
\text { Group } \\
(n=50)\end{array}$} & \multirow[t]{2}{*}{\begin{tabular}{|c|} 
Chi- \\
Square \\
Value \\
\end{tabular}} & \multirow[t]{2}{*}{$\begin{array}{c}\mathbf{p} \\
\text { value }\end{array}$} \\
\hline & & $\begin{array}{c}\text { Number } \\
\text { of } \\
\text { Placenta }\end{array}$ & $\%$ & $\begin{array}{c}\text { Number } \\
\text { of } \\
\text { Placenta }\end{array}$ & $\%$ & & \\
\hline 1 & \multicolumn{7}{|c|}{ Calcification } \\
\hline & Absent & 38 & 76 & 46 & 92 & \multirow{2}{*}{4.76} & \multirow{2}{*}{$0.029^{*}$} \\
\hline & Present & 12 & 24 & 4 & 8 & & \\
\hline 2 & \multicolumn{7}{|c|}{ Infarction } \\
\hline & Absent & 22 & 44 & 41 & 82 & \multirow{2}{*}{15.49} & \multirow{2}{*}{$\begin{array}{c}<0.001 \\
*\end{array}$} \\
\hline & Present & 28 & 56 & 9 & 18 & & \\
\hline \multicolumn{8}{|c|}{ 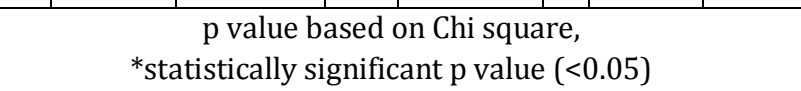 } \\
\hline \multicolumn{8}{|c|}{$\begin{array}{c}\text { Table 2. Association of Infarction and Calcification } \\
\text { between Anaemia and Control Group }\end{array}$} \\
\hline
\end{tabular}

\begin{tabular}{|c|c|c|c|c|c|}
\hline Group & $\begin{array}{c}\text { Percentage } \\
\text { of Villi with } \\
\text { Syncytial } \\
\text { Knots }\end{array}$ & $\begin{array}{l}\text { Number } \\
\text { of } \\
\text { Placenta }\end{array}$ & $\%$ & $\begin{array}{c}\text { Chi- } \\
\text { Square } \\
\text { Value }\end{array}$ & $\begin{array}{c}\mathbf{p} \\
\text { value }\end{array}$ \\
\hline \multirow{2}{*}{ Anaemia } & $\leq 30 \%$ & 18 & 36 & \multirow{4}{*}{26.27} & \multirow{4}{*}{$<0.001^{*}$} \\
\hline & $>30 \%$ & 32 & 64 & & \\
\hline \multirow{2}{*}{ Control } & $\leq 30 \%$ & 43 & 86 & & \\
\hline & $>30 \%$ & 7 & 14 & & \\
\hline \multicolumn{6}{|c|}{$\begin{array}{c}\text { p value based on Chi square, }{ }^{*} \text { statistically significant } p \\
\text { value }(<0.05)\end{array}$} \\
\hline
\end{tabular}

\begin{tabular}{|c|c|c|c|c|c|}
\hline Group & $\begin{array}{c}\text { Particulars } \\
\text { of Villous } \\
\text { Vascularity }\end{array}$ & $\begin{array}{c}\text { Number } \\
\text { of } \\
\text { Placenta }\end{array}$ & $\%$ & $\begin{array}{c}\text { Chi- } \\
\text { square } \\
\text { Value }\end{array}$ & $\begin{array}{c}\mathbf{p} \\
\text { value }\end{array}$ \\
\hline \multirow{3}{*}{ Anaemia } & Normal & 20 & 40 & \multirow{6}{*}{16.88} & \multirow{6}{*}{$<0.002^{*}$} \\
\hline & Increased & 5 & 10 & & \\
\hline & Decreased & 25 & 50 & & \\
\hline \multirow{3}{*}{ Control } & Normal & 35 & 70 & & \\
\hline & Increased & 9 & 18 & & \\
\hline & Decreased & 6 & 12 & & \\
\hline \multicolumn{6}{|c|}{$\begin{array}{l}\text { p value based on Chi square, } \\
\text { *statistically significant } p \text { value }(<0.05)\end{array}$} \\
\hline \multicolumn{6}{|c|}{$\begin{array}{l}\text { Table 4. Association of Villous Vascularity } \\
\text { between Anaemia Group and Control Group }\end{array}$} \\
\hline
\end{tabular}

\begin{tabular}{|c|c|c|c|c|c|}
\hline Group & \begin{tabular}{|c|}
$\begin{array}{c}\text { Percentage } \\
\text { of }\end{array}$ \\
Villi Showing \\
Fibrinoid \\
Necrosis
\end{tabular} & $\begin{array}{c}\text { Number } \\
\text { of } \\
\text { Placenta }\end{array}$ & $\%$ & $\begin{array}{l}\text { Chi- } \\
\text { Square } \\
\text { Value }\end{array}$ & $\begin{array}{c}\mathbf{p} \\
\text { value }\end{array}$ \\
\hline \multirow{2}{*}{ Anaemia } & $\leq 3$ & 21 & 42 & \multirow{4}{*}{28.27} & \multirow{4}{*}{$<0.001^{*}$} \\
\hline & $>3$ & 29 & 58 & & \\
\hline \multirow{2}{*}{ Control } & $\leq 3$ & 46 & 92 & & \\
\hline & $>3$ & 4 & 8 & & \\
\hline \multicolumn{6}{|c|}{$\begin{array}{l}\text { p value based on Chi square, } \\
\text { *statistically significant p value }(<0.05)\end{array}$} \\
\hline \multicolumn{6}{|c|}{$\begin{array}{l}\text { Table 5. Association of Fibrinoid Necrosis } \\
\text { between Anaemia Group and Control Group }\end{array}$} \\
\hline
\end{tabular}




\begin{tabular}{|c|c|c|c|c|c|}
\hline \multirow{2}{*}{ Groups } & $\begin{array}{c}\text { Percentage } \\
\text { of } \\
\text { Fibrotic Villi }\end{array}$ & $\begin{array}{c}\text { Number } \\
\text { of } \\
\text { Placenta }\end{array}$ & \% & $\begin{array}{c}\text { Chi- } \\
\text { Square } \\
\text { Value }\end{array}$ & $\begin{array}{c}\mathbf{p} \\
\text { value }\end{array}$ \\
\hline \multirow{2}{*}{ Anaemia } & $\leq 3$ & 21 & 42 & & \\
\cline { 2 - 4 } & $>3$ & 29 & 58 & \multirow{2}{*}{28.27} & $<0.001^{*}$ \\
\hline \multirow{2}{*}{ Control } & $\leq 3$ & 46 & 92 & & \\
\cline { 2 - 4 } & $>3$ & 4 & 8 & & \multicolumn{3}{|c|}{ Table 6: Association of Fibrotic Villi } \\
\hline \multicolumn{5}{|c|}{ between Anaemia Group and Control Group } \\
\hline
\end{tabular}

\section{DISCUSSIONS}

In the present study, total of 100 placentas were studied which included 50 from mothers with uncomplicated pregnancies, considered as control group and 50 from mothers with anaemia, considered as anaemia group. The macroscopic and microscopic lesions were quantified and compared between the two groups. The incidence of anaemia in multigravida (58\%) is more when compared to primigravida (42\%). The mean weight of the placenta in anaemia group $(438.0 \pm 40.56 \mathrm{~g})$ was less compared to control group $(476.8 \pm 33.16 \mathrm{~g})$. Mongia et al 8 in his study observed that decreased placental weight in low haemoglobin concentration, similar to the present study. But Beischer et $\mathrm{al}^{9}$ and Lao et $\mathrm{al}^{10}$ in their study observed that the maternal anaemia was associated with placental hypertrophy.

In the present study, correlation between the placental weight and birth weight indicated a positive correlation in both anaemia and control groups. This indicates that if the placental weight decreases the birth weight of the infant also decreases. Ren et al 11 in their study observed that in maternal anaemia, the foetal weight decreases as the placental weight decreases. The results were similar in the current study. Placental coefficient is defined as the ratio of placental weight to foetal weight. Normally it is 0.10 to 0.18 . The placental coefficient decreases as the placental weight increases and high placental co-efficient is seen if the placental weight decreases. ${ }^{12}$

In the present study, placental coefficient in anaemia group $(0.18 \pm 0.02)$ is more when compared to control group $(0.17 \pm 0.01)$. Similar results were seen in the study conducted by Rangnekar AG et al ${ }^{13}$ The mean length of the umbilical cord in anaemia group was less $(49.72 \pm 5.29 \mathrm{~cm})$ when compared to control group $(54.46 \pm 3.12 \mathrm{~cm})$. These results were similar to the study conducted by Adil et al. ${ }^{14}$

Calcification is common in human placenta and it is a normal feature of maturation and senescence of this organ. Increased calcification of placenta has complications like foetal growth restriction and foetal distress. Tindall et al ${ }^{15}$ in their study reported that placental calcification was low in anaemia. But in the current study, placental calcification was seen more in anaemia group (24\%) when compared to control group (8\%). In current study, placental infarcts were found to be significantly more in anaemia group (56\%) when compared to control group (18\%). Begum et $\mathrm{al}^{16}$ and Huang et $\mathrm{al}^{17}$ observations were similar to the present study. In the current study, the mean number of placental cotyledons were significantly increased in anaemia group $(18.9 \pm 3.02)$ when compared to control group $(17.46 \pm 1.58)$. The results were similar to the study conducted by Mongia et al. ${ }^{8}$ Knots in more than $30 \%$ of the villi are considered excessive. In the present study, syncytial knot counts were more in anaemia group (64\%) when compared to control group (14\%). Mongia et al ${ }^{8}$ and Kristina et al ${ }^{18}$ studied histological features of placenta in anaemia which showed an increase in the number of syncytial knots.

The villi of the mature placenta usually contains between 2-6 capillary vessels which are sinusoidally dilated. In the present study, there was significant decrease in villous vascularity in anaemia group (50\%) as compared to control group (12\%). Joshi et al ${ }^{19}$ in their study observed that villous hypovascularity was seen in anaemic mothers. Placenta in which fibrinoid necrosis involving up to 3 percent of placental villi is considered as normal and placenta in which the percentage of villi showing fibrinoid necrosis of more than three percent is considered as abnormal. ${ }^{20}$ In the present study, fibrinoid necrosis was more in anaemia group (58\%) when compared to control group (8\%). Mehrota et al ${ }^{21}$ and Joshi et al 20 in their study observed increased intravillous and perivillous fibrin deposition. Both of their results were in concurrence to the present study. In term placenta, less than 3 percent of villi show fibrosis, and if more than 3 percent of villi in a placenta show fibrosis it is considered as abnormal. ${ }^{22}$ In the present study, fibrotic villi were more in anaemia group (58\%) when compared to control group (8\%). Usha Rusia et $\mathrm{al}^{23}$ and Mehrota et $\mathrm{al}^{22}$ observed that villous fibrosis increases in amount with increasing grade of anaemia. Both of their results were similar to the present study.

\section{CONCLUSIONS}

Placenta depicts the most accurate record of prenatal experience of an infant and it undergoes different changes in weight, volume, structure, shape and function continuously throughout the gestation to support the prenatal life. Placental morphology plays a vital role in both maternal and foetal wellbeing during pregnancy. Macroscopic examination of placenta in anaemia showed decreased mean foetal birth weight, placental weight and cord length. There was increased incidence of increased number of cotyledons, calcification and infarction. Microscopic examination of placenta in anaemia showed excessive syncytial knots, increased fibrinoid necrosis, increased fibrotic villi, and decreased villous vascularity. Anaemia in pregnancy alters the placental morphology. Early recognition of anaemia and proper management may therefore be crucial for normal placental function. Thus, we conclude that histopathological examination of placenta is indispensable and has to be carried out as a routine protocol.

\section{REFERENCES}

1. Kulandaivelu AR, Srinivasamurthy BC, Murugan A, et al. Morphology and morphometric study of human placenta in rural southern India. British Journal of Medicine and Medical Research 2014;4(15):2995-3008.

2. Narasimha A, Vasudeva DS. Spectrum changes of placenta in toxemia of pregnancy. Indian J Pathol Microbiol 2011;54(1):15-20.

3. Dow P, Torpin R. Placentation studies: correlation between the size of the sac, area of placenta, weight of the placenta and weight of baby. Hum Biol 1939;11:248.

4. Klebanoff MA, Shrono PH, Selby JV, et al. Anaemia and Spontaneous preterm birth. Am J Obstet Gynecol 1991;164(1 Pt 1):59-63.

5. World Health Organization. Report of working group on anaemia. 1992;11:212-5. 
6. Stacey E, Carter D, Greenson GK, et al. Sternberg's diagnostic pathology: the placenta. $4^{\text {th }}$ edn. Philadelphia: Lippincott Williams and Wilkins 2006:2072-6.

7. Fox H. Pathology of placenta. $2^{\text {nd }}$ edn. Philadelphia: WB Saunders Co.Ltd., 1997.

8. Mongia SM, Jain SK, Yadav M. Placenta: the wonder organ. J Indian Acad Forensic Med 2011;33(2):140-2.

9. Beischer NA, Sivasamboo R, Vohra S, et al. Placental hypertrophy in severe pregnancy anaemia. J Obs Gynaecol Br Cwlth 1970;77(5):340-409.

10. Lao TT, Wong WM. Placental ratio - its relationship with mild maternal anaemia. Placenta 1997;18(7):593-6.

11. Ren A, Wang J, Ye RW, et al. Low first-trimester hemoglobin and low birth weight, preterm birth and small for gestational age newborns. Int J Gynaecol Obstet 2007;98(2):124-8.

12. Little WA. The Significance of placental/fetal weight ratios. Am J Obstet Gynecol 1960;79:134-7.

13. Rangnekar AG, Darbari R. Placental changes in pregnancy anaemia. Study of one hundred cases. J Obstet Gynaecol India 1993;43:473-8.

14. Adil SAK, Nausheen R. Histopathological study of placenta in severe anemia during pregnancy. J Evo Med Dent Sci 2012;4:616-23.

15. Tindall VR, Scott JS. Placental calcification: a study of 3,025 singleton and multiple pregnancies. J Obstet Gynaec Br Cwlth 1965;72:356-73.
16. Begum M, Ara S, Kishwara S, et al. Microscopic changes of the placental components in maternal anemia. Bangl J Anat 2010;8(2):59-63.

17. Huang A, Zhang R, Yang Z. Quantitative (Stereological) study of placental structures in women with pregnancy iron-deficiency anemia. Eur J Obstet Gynecol Reprod Biol 2001;97(1):59-64.

18. Kristina L, Raanan S, Rebecca B. Syncytial knots as a reflection of placental maturity: reference values for 20 to 40 weeks gestational age. Pediat Develop Path 2009;28:28-37.

19. Joshi H, Desai M, Desai $P$, et al. Fetal bearings of histopathological changes in placentae of mothers with severe and moderate anemia. J Obstet Gynaecol India 1996;46(1):13-4.

20. Fox H. Fibrinoid necrosis of placental villi. J Obstet Gynaec Br Cwlth 1968;75(4):448-52.

21. Mehrotra VG, Mukherjee $\mathrm{K}$, Pandey $M$, et al. The histological study of placenta in normal and abnormal pregnancy. J Obstet Gynaecol, India 1972;22:248.

22. Fox H. Fibrosis of placental villi. J Pathology and Bacteriology 1968;95(2):573-9.

23. Rusia U, Kapor S, Madan N, et al. Placental morphology and histochemistry in iron deficiency anaemia. Ind J Med Res 1998;87:468-74. 